\title{
高分子材料の分割硬化法によるレーザー三次元造形
}

\author{
小幡 孝太郎 \\ Laser Zentrum Hannover e. V. (Hollerithallee 8, 30419 Hannover, Germany)
}

\section{Laser Based 3D Printing of Photo-Sensitive Polymer Material by Clustered Photo-Polymerization Technique}

\author{
Kotaro OBATA \\ Laser Zentrum Hannover e. V., Hollerithallee 8, 30419 Hannover, Germany
}

(Received February 22, 2018)

\begin{abstract}
3D structuring using photo-sensitive polymers is an attractive additive manufacturing technique. In this technique, 3D structuring is achieved by layer-by-layer process in which 2D patterns of photopolymerized layers are stacked. In this paper, general feature and example of the precision 3D structures fabricated by micro-stereolithography method based on single-photon polymerization are described. In addition, advanced technique using stack of clustered 2D patterns has been demonstrated in order to decrease the adhesion strength between polymerized structure and laser input aperture window for the regulated liquid surface method in the micro-stereolithography technique.
\end{abstract}

Key Words: UV laser, 3D print, Micro-stereolithography, Photo-sensitive polymer, Regulated liquid surface method

\section{1. はじめに}

近年, 3 次元データをもとに, 液状の感光性高分子材 料, 可燃性樹脂, 粉末状金属などの材料に対して, レー ザー光, 電子ビーム, 溶融, インクジェット方式などを 用いて任意の形状の積層構造を形成する三次元積層造形 法は, 従来のモールド技術や切削工具などを用いず, 複 雑な3次元構造体を高精度に作成できる ${ }^{1,2)}$ 。これらの積 層造形装置は総称として3Dプリンターと呼ばれ, 産業 用3Dプリンターに加えて, 個人向け3Dプリンターの爆 発的な広がりもあり, その技術的知名度は確たるものと なっている。アメリカInternet Data Center(IDC)の報告に よると, 装置とその周辺を含めた市場規模は, 2020年に は354億USドルに達すると見込まれている゙。この予測 は, 今後の3Dプリンター用の新素材開発や新たな分野 への利用拡大など，様々な応用が実現されることによっ て, さらなる拡大も秘めている。

本稿では，これらの中で最も古い歴史を持つとともに 高精度, 高分解能の三次元造形が可能な紫外レーザーを 用いた高分子材料のマイクロステレオリソグラフィ法 (液相光重合法(光造形法))について, 事例とその応用に ついて紹介する。
2. マイクロステレオリソグラフィ法による三次元造形

高分子材料のマイクロステレオリソグラフィ法は, 液 状の感光性樹脂(ポリマー材料)を満たした槽に紫外線 レーザーを照射し，一層ずつ樹脂を硬化させ積層す る る $^{3-5)}$ Fig. 1 に本稿で用いたマイクロステレオリソグラ
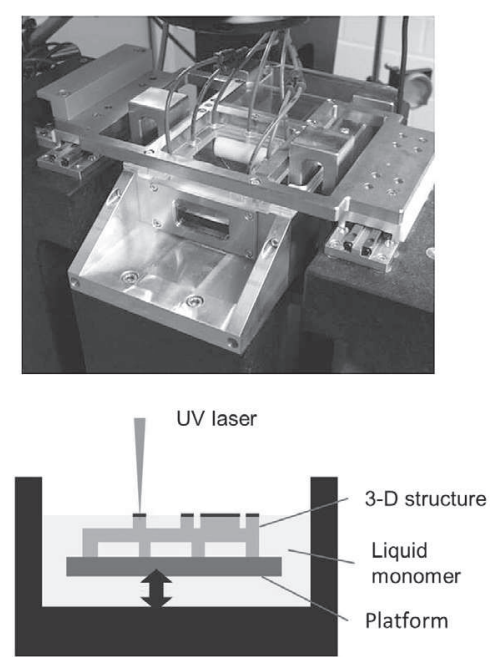

Fig. 1 Micro-stereolithography setup.

\footnotetext{
${ }^{\dagger}$ https://www.idc.com/getdoc.jsp?containerId=IDC_P33192.
} 
フイ光造形装置の概略図を示す ${ }^{6)}$.

波長355 nm (CW)の紫外レーザー光は, Acousto Optical Modulator (AOM) による照射レーザー光のON/OFF制御と レーザー光強度を調整後, ガルバノスキャナーミラーで ポリマー材料 (ORMOCORE ${ }^{\circledR}$, Microresist $\left.\mathrm{GmbH}\right)$ の液面上 へ2次元パターンを描画した。 また，レーザー光は， $f=$ $100 \mathrm{~mm}$ の $f$ - $\theta$ レンズによって液面上へ集光照射した。硬 化させる2次元パターンの厚みは，材料自身のレーザー 光に対する化学的反応性とレーザー光の照射条件を制御 することによって均一なレイヤー厚さが得られるように 最適化した. ポリマー材料が硬化した後, 槽中の高精度 位置決めステージを下降させて, さらに2次元パターン 状に硬化させたポリマー層を積層させる。この積層を所 定の3次元データをもとに繰り返すことによって, 所望 の3次元構造体を作製した，上記のような，レーザー光 を硬化したポリマーの上面から照射するような構成(自 由液面法) は, 構造体作成中に機械的干涉が全くないた め微細構造体の製作に適している.

\section{3. 規制液面法}

Fig. 2 にマイクロステレオリソグラフィーによって作 製された三次元造形の例 (エッフェル塔)を示す。構造作 成のために，レーザーの走査速度およびレーザー強度を それぞれ $1000 \mathrm{~mm} / \mathrm{s}, 25 \mu \mathrm{W}$ で, 高さ $5 \mathrm{~mm}$ (レイヤー厚 さ10 $\mu \mathrm{m})$ の構造体を作成した，構造体表面に付着して いる未硬化部分の液状ポリマー材料は, 現像液によって 洗浄除去した。 ポリマー材料に添加されている架橋剤が 誘起する光化学反応 (重合反応)に対するレーザー光の照 射条件 (波長, 強度, 走査速度) は最適化されており, 構

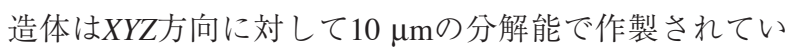
ることが光学的観察で確認できる. また, 本稿で用いら

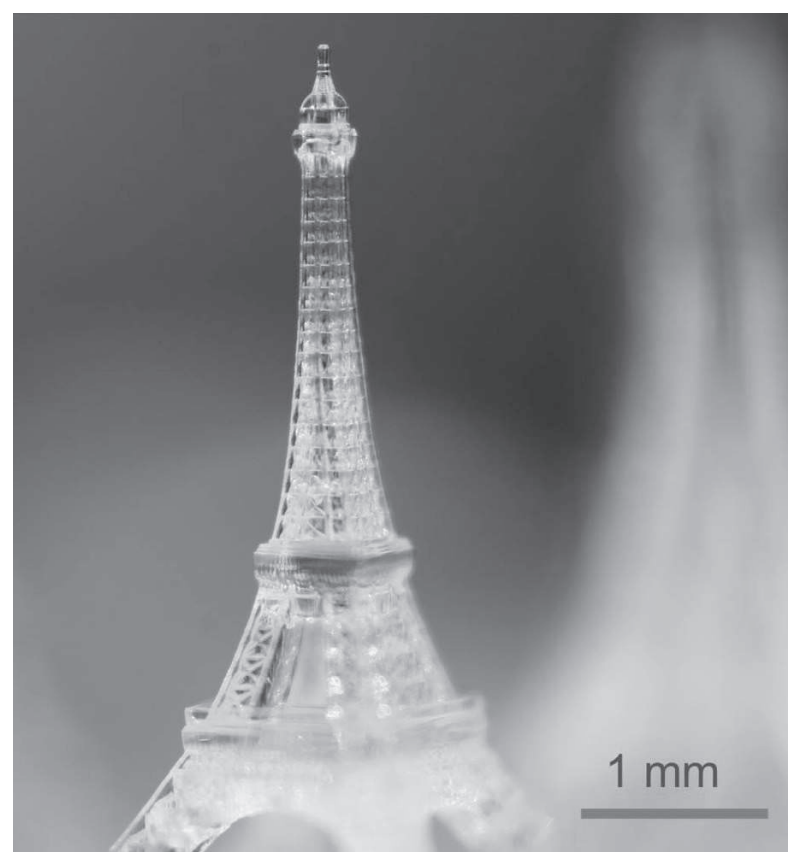

Fig. 2 Example of 3D structure fabricated by $\mu$-stereolithography (Eiffel tower).
れたORMOCORE ${ }^{\circledR} は$, 最適なレーザー光の照射条件で の体積収縮の影響が少ないポリマー材料であるため, 作 製した構造に歪みは見られなかった。

マイクロステレオリソグラフイ法で，3次元構造体を 作製する場合，光硬化前のポリマー材料の均一な平面を 維持することが重要となってくる. 自由液面法で積層を 行う場合, 新たに形成された液体層の表面は, すでに光 硬化した下部に存在する構造体との表面張力によって Fig. 3 (a) に示すように周辺部に沿って歪む.この歪みの 影響は, 造形されたエッジ周辺が最も影響が出るため, レイヤー厚さが安定するまで待機時間をとるか, 界面活 性剂などの添加剤により，ポリマー材料の表面張力を制 御する必要がある。近年では，この問題を解決するため にFig. 3(b) に示すような2枚の基板でポリマー材料を挟 み込んで積層の光硬化を構成する手法(規制液面法)が主 流となっている。この手法では, ポリマー層をレー ザー照射により1層硬化させるたびに所定の厚みとなる ように片方の基板位置を高精度位置決めステージなどで 移動させることによって所望のレイヤー厚さとなるポリ マー層を新たに形成する。これらの操作を繰り返し，2 次元パターンの光硬化を積層させることによって所望 の3次元構造を形成している。 その結果, 規制液面法で 積層した構造体は, 自由液面法で述べた表面張力の 影響による造形不良が発生しない。 また，造形液面が空 気層に接していないので酸素による光化学反応の阻害を 受けにくい長所を持つ。一方で, レーザー光は片側の基 板を通して常に照射されるため, 光硬化した構造体と 基板の間で過度の密着が生じ, 剥離時に造形物の破 損,または歪みが生じる可能性がある。一般的には, Polydimethylsiloxane (PDMS)のような紫外レーザー光に

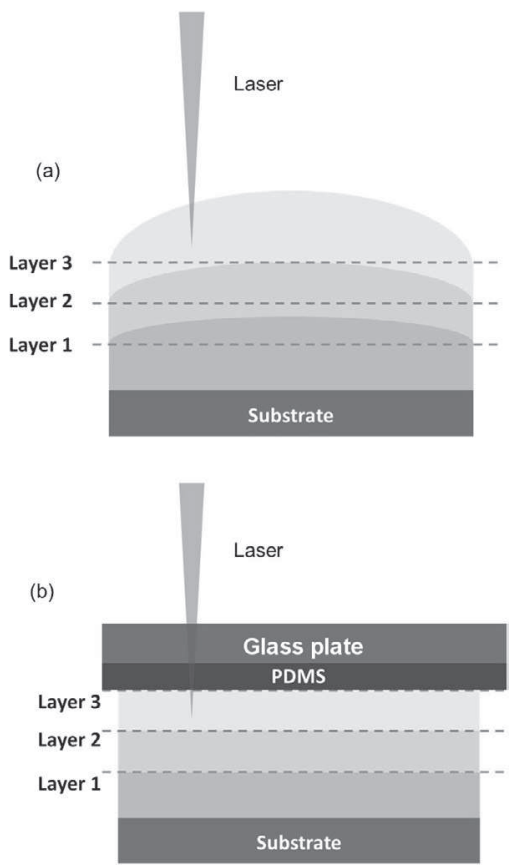

Fig. 3 Layer-by layer process in $\mu$-stereo lithography with different principles of deposition method: (a) Free surface technique, (b) Constrained surface technique with low-sticking coating (PDMS). 
対して透過率が高く，ポリマー材料に対して剥離性が高 い薄膜を基板にコーティングする工夫によって, 密着性 を低減させることが可能である。しかし，上記の工夫を した場合でも, 剥離層との接触面積が最大となる一枚板 のような造形物を形成した場合, 造形物の破損, または 歪みが生じる過度の密着が発生することがある。

\section{4. 分割硬化法}

規制液面法に扔いる密着性の問題は, 剥離層の形成の 他に，レーザー照射を工夫することによって効果的な改 善が期待できる。本稿では, Fig. 4 に示すような, 最終 的な一体物の構造体をハニカム構造などの周期的な構造 で分割し，各レイヤーで形成された構造体に生じる，基 板との接触面積を最小限にして形成する手法を検討し た，本手法は，層内で光硬化する2次元パターンを一度 に全領域を誘起するのではなく一部のみに限定する。こ のとき, 剥離性は分割した構造体の縁の長さに反比例し て低下するので, 構造体を小さく細分化するほど高い剥 離性が期待できる. 未硬化の領域は, 後続の層で硬化 し, 最終的に1層分の 2 次元パターンが複数のレイヤーに よって形成される。一例として，1層の厚さを $10 \mu \mathrm{m}$ と して構造体を作成した場合, Fig. 4 のハニカム構造

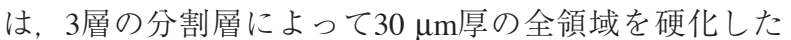
層を最終的に形成する，各層でレーザー光が走査されな い領域は，未硬化となっているがレーザー光の侵入深さ が十分にあることから，後続の層でレーザー光が走査さ れるときに一括で硬化されることによって, 最終的に全 照射領域が光硬化した構造を形成する。この手法で積層 構造を作製した場合, 構造体の硬化領域と剥離層との接 触面積を減少させることによって接着力を低下させるだ けでなく、レーザーの走查距離は全領域を一度に形成す る従来法よりも $1 / n$ (nは分割数)に短縮することができ る. Fig. $5(\mathrm{a})$ に, 本手法により作成した 3 次元構造体の写 真を示す。実験は, 直径 $20 \mathrm{~mm}$, 厚さ $1 \mathrm{~mm}$ の円盤形状の
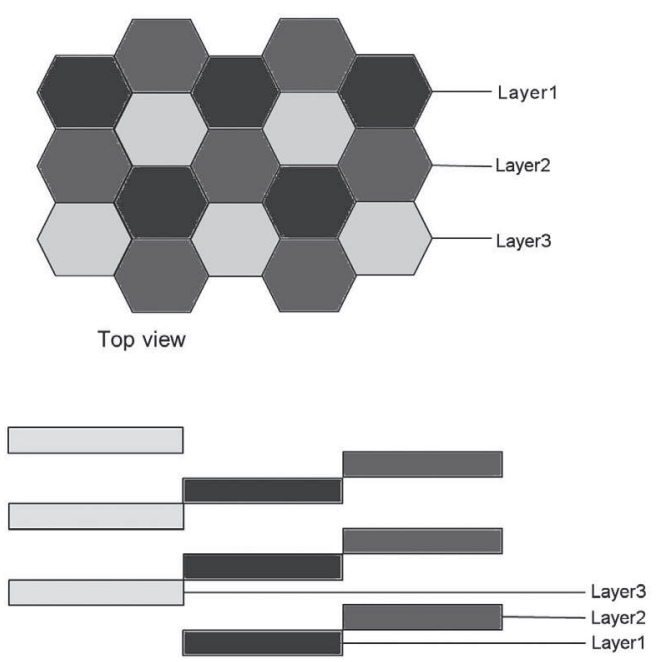

Side view

Fig. 4 Schematic illustration of honeycomb structure for photo-polymerization of clustered parts.
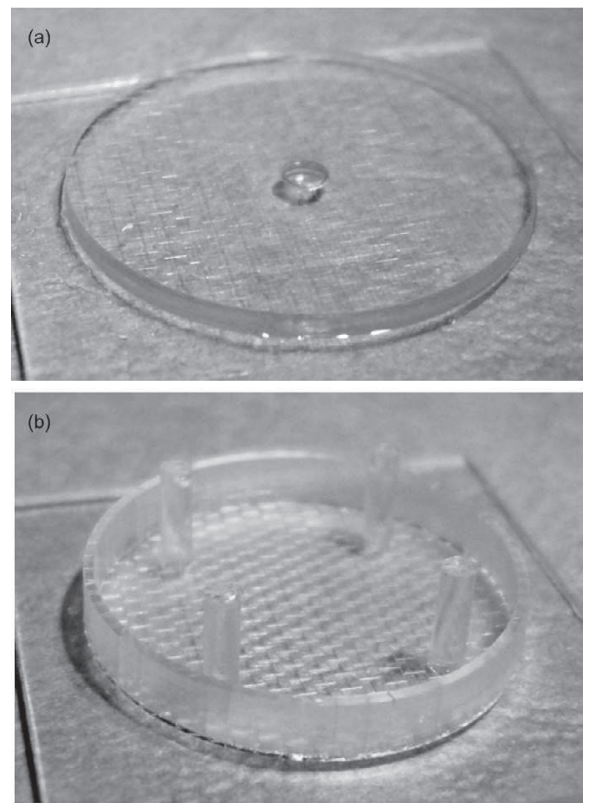

Fig. $520 \mathrm{~mm}$ diameter disk structure fabricated by the photo-polymerization of the clustered parts: (a) $20 \mathrm{~mm}$ diameter disk, (b) $20 \mathrm{~mm}$ disk with ring and pillars.

作製を試みた。本稿で用いられた剥離層(PDMS薄膜)で は，従来法で全領域を硬化させて積層すると，硬化領域 と剥離層が強く密着してしまい積層プロセスを継続する ことができなかった，一方で，密着性を低下させるため に各層で $0.5 \times 0.5 \mathrm{~mm}^{2}$ の正方形の分割パターンを構成 し，9層で円盤形状の全領域の硬化を試みた場合，十分 な剥離性を維持して積層構造を形成できた，1層当たり の厚さは，高精度ステージ制御により1 1 m ステップで移 動させ，1000層繰り返すことによって円盤状の構造体が 作成された，加工時間は，前述のと扮り9層分の厚さ $(9 \mu \mathrm{m})$ で全領域を硬化させた従来法と同等である.

Fig. 5(b) にFig. 5(a) 作製された円盤形状の構造体の上に さらに円柱 (直径 $1 \mathrm{~mm}$ ), およびリング状構造(外周部直 径 $20 \mathrm{~mm}$, 厚さ $0.5 \mathrm{~mm}$ ) を追加作製した写真を示す. 従来 法でリング状構造を作成した場合，リング内側部分に密 閉された空間が発生してしまい, 密閉空間内のポリマー の品質が劣化する問題が発生した。一方, 分割して構造 体を作製した場合，常に液状のポリマー材料が分割して 硬化した領域の隙間から循環するので, 均一な加工品質 を維持した3次元構造体が作成された。 また，本手法は， 構造体のアスペクト比への影響は見られなかった。

\section{5. まとめ}

紫外レーザーを用いた高分子材料のマイクロステレオ リソグラフイ法について, 事例と技術的な課題と改善策 について述べた，光造形法が発明されてからすでに30年 以上が経過し，ものづくりの世界，特に日本の基幹産業 の試作として広く利用されている。 さらに近年3Dプリン ターが周知されたことにより，3Dプリンターを通して今 まで以上に試作から商品立案・実用化までのプロセスを 
短縮化している。 また, 個人の活動を中心とした, 表 現・デザイン・ファッション・芸術などの分野で3Dプリ ンターが広く展開され始めている. 今後, 高分子材料の 光造形法は, 高分子材料が得意とする光学的, 化学的特 性を利用する分野や, 高精度・高精細が求められるナノ テクノロジー分野，さらにバイオアプリケーションへの 発展が期待される。これらの条件を満たす構造体を作製 するには，工学的な造形方法の検討だけではなく，新規 特性を持ったポリマー材料の化学的合成技術の研究など, 多方面にわたっての研究を進めていくことが求められる.

\section{参考文献}

1）塚本 雅裕：レーザー研究 42 (2014) 814.

2) 新野 俊樹：レーザー研究 42 (2014) 817.

3) K. Ikuta, T. Ogata, M. Tsubio, and S. Kojima: Proc. IEEE Micro Electro Mechanical Systems 1996 (MEMS'96) (1996) 301.

4) T. Nakamoto, K. Yamaguchi, P. A. Abraha, and K. Mishima: J. Micromech. Microeng. 6 (1996) 240.

5) X. Zhang, X. N. Jiang, and C. Sun: Sensors and Actuators A 77 (1999) 149

6) A. Neumeister, R. Himmelhuber, C. Materlik, T. Temme, F. Pape, H. H. Gatzen, and A. Ostendorf: J. Laser Micro/Nano-Eng. 3 (2008) 67. 